\title{
A SIMPLE PARAFFIN EMBEDDED PROTOCOL FOR FISH EGG, EMBRYO, AND LARVAE
}

\author{
Gratiana E Wijayanti, Priadi SETyaWAN, DWi Indah KuRniaWATI
}

Fakultas Biologi, Universitas Jenderal Soedirman, Jalan dr. Suparno 63 Purwokerto 53122

\section{A B S T R A C T}

This paper describes a simple protocol of paraffin-embedded histological section for fish eggs, embryo and larvae of the hard-lipped barb and the giant gourami. The specimens were fixed in Bouin solution, washed in 70\% ethanol, then were dehydrated in a series of ethanol solution of increasing concentration until absolute ethanol was reached. The specimens were cleared in graded xylene and were infiltrated with liquid paraffin then were embedded in pure paraffin. Upon sectioning, at 4-5 $\mu \mathrm{m}$ thick the specimens were attached to the gelatin-coated glass slide and let to dry at room temperature or $37^{\circ} \mathrm{C}$ overnight. The specimens were deparaffinized in xylene, rehydrated then were stained with hematoxylin and eosin. After being dehydrated in graded ethanol, the specimens were cleared in xylene and were mounted with an organic mounting agent. Any step in preparing histological section including samples collection, fixation, dehydration, infiltration and embedding might contribute to the quality of histological features. A proper knowledge of the tissues beeing processed, fixative solution and the histological techniques is essential to gain good results. Bouin fixative is preferable to fix fish larvae and produce a good histological feature. Decalcification is necessary to produce a good histological section on the specimens containing bone.

KEY WORDS: paraffin embedded, fish embryo, fish larvae, Osteochilus vitatus, Osphronemus goramy

Corresponding Author: Gratiana E Wijayanti | email: 1.bugrat@gmail.com

\section{N T RO D U C T I O N}

The most routinely employed techniques of histological preparation is the paraffin embedded sections. Since it first publication by Professor Edwin Klebs in early 1860s (Sanderson et al., 2013), paraffin embedded sections had served as an important tool in the field of biomedical (Grave, 2007; Treuting et al., 2012) as well as developmental biology (e.g. Balogh and Sótonyi, 2003; Habashy et al., 2012; Mathew and Appel, 2016). Using histological examination scientists can detect a stable condition or early sign of diseases not easily recognized by a morphological examination. The paraffin-embedded section in combination with immunoreaction has developed into a powerful technique to study tissue lineage and fate map, the immunohistochemistry.

The paraffin-embedded technique has been widely used in fish research to study general structure of various organs as well as their pathological examination (Takashima and Hibiya, 1985; Palikova et al., 2004). Protocols for processing various fish organs are readily available for example eyes (Nuckel and Gross, 2007), gills, liver, kidney (Carmago and Martinez, 2007) and gonad (Wijayanti et al., 2009). However, paraffin embedded protocol for egg, embryo, and larvae are less. One of the most comprehensive protocols for fish larvae was developed by Sabaliaukas et al. (2006) enabling to process a large number of zebrafish larvae at the same time. This protocol, however, needs more sophisticated equipment such as acrylic mold and automated-closed reagent type tissue processor which is not always available in other laboratories.

Each laboratory has developed their unique protocols suitable for the specimen studied. The variation in processing tissues for paraffin embedded section might involve the use of different fixative, de- hydrant, clearing agent and staining solution (e.g. Matsuda et al., 2011). It also varied in time allocation of each step according to the specimen size and tissue texture (Wijayanti, 2003). Inappropriate selection of fixative and staining might result in an artifact leading to incorrect interpretations; it might also lead to the unnecessary repetition of the procedure. Therefore, it is worthy to share a working protocol to avoid loose of valuable material, time and money. This paper discusses a simple method of a paraffin-embedded technique for fish egg, embryo, and larvae.

\section{METHODS}

Materials. The hard lipped barb (Osteochilus vittatus L.) embryos (ranging from 2 cell stage to pre-hatching stage) and larvae ( 1 to 7 -days post-hatching $=d p h$ ), the giant gourami (Osphronemous gourami Lac) egg and larvae, and the Paraplast pastilles (melting point $56-58^{\circ} \mathrm{C}$ ).

Solution. A 4\% Paraformaldehyde (PFA) in PhosphateBuffered Saline (PBS), Bouin solution, ethanol, xylene, Harris hematoxylin, aqueous eosin (0.5\%), Scott water, mounting medium (Enthelan New, Merk HX308279), 1\% aqueous gelatine and distilled water.

Equipment. Tweezers, transfer pipettes, specimen bottles, frosted microscope slide, coverslips $(24 \times 24 \mathrm{~mm}$, Assistant), tissue processing jars, staining jars, paraffin mold, specimen holders, rotary microtome, water bath, disposable microtome blades, $60^{\circ} \mathrm{C}$ incubation oven, slide rack and water bath.

Specimen collection. The hard-lipped barb embryos and larvae were prepared by assisted fertilization of oocytes and sperm obtained from induced spawning. The giant gourami eggs were aspirated by cannulation, and the larvae were obtained from natural spawning. The embryos were removed from the incubation container using a wide-mouth transfer pipette and placed into specimen bottle containing a fixative solution. The larvae were anesthetized by placing them in cold water $\left( \pm 4^{\circ} \mathrm{C}\right)$, once the larvae were immobile, they were removed and placed into specimen bottle containing a fixative solution.The specimen properly were coded according to their species and stage of development. 
Fixation. The embryos were fixed in Bouin solution for 2 hours then were moved to $70 \%$ ethanol. The larvae less than $10 \mathrm{dph}$ were fixed in 4\% PFA in PBS for 24 hours in a refrigerator, rinsed three times in PBS then kept in $70 \%$ ethanol. The larvae older than 10dph were fixed in Bouin solution for 2-7 days (according to the size of the larvae), rinse in $70 \%$ ethanol then were rehydrated in $50 \%$ ethanol, $30 \%$ ethanol then distilled water for 30 minutes each.The specimen were put into $5 \%$ trichloroacetic acid for 24 hours (10-20 dph) or 36 hours (for 30-60 dph) to decalcify the bone. The specimen were rinsed in distilled water three times then were re-hydrated in an increasing ethanol series starting from $30 \%$ ethanol. Following fixation, the larvae with total length more than $20 \mathrm{~mm}$ were transversally cut into half for embedding purposes.

Dehydration. This process was carried out by immersing specimens in a series of ethanol solutions of increasing concentration until absolute ethanol was reached. The series of increasing concentrations was used to avoid excessive distortion of the tissue. The dehydration sequence for the embryos was:
1. $70 \%$ ethanol
2. $80 \%$ ethanol
3. $90 \%$ ethanol
4. $100 \%$ ethanol
5. $100 \%$ ethanol
30 minutes
30 minutes
30 minutes
30 minutes
30 minutes

A 10 minutes was added for each step to process larvae.

Clearing. This step was conducted to displace the ethanol in the tissue using an intermediate solvent that is entirely miscible with ethanol and paraffin. In this study, xylene was used as a solvent. The xylene will, in turn, be displaced by the liquefied paraffin during the infiltration step.The clearing process will also remove a substantial amount of fat from the tissue which otherwise presents a barrier to paraffin infiltration. The clearing sequence for the embryos was:
1. Ethanol : xylene $(3: 1 \mathrm{v} / \mathrm{v})$
20 minutes
2. Ethanol : xylene $(1: 1 \mathrm{v} / \mathrm{v})$
20 minutes
3. Ethanol : xylene $(1: 3 \mathrm{v} / \mathrm{v})$
20 minutes
4. Xylene
5. Xylene
30 minutes
30 minutes

A 10 minutes was added for each step to process larvae.

Paraffin infiltration. This step was conducted to displace the xylene with paraffin completely. The process was carried out in an oven incubator at a temperature of $60^{\circ} \mathrm{C}$ to prevent the paraffin from solidifying. The infiltration sequence for embryo was:

1. Xylene : paraffin $(3: 1 \mathrm{v} / \mathrm{v}) 20$ minutes

2. Xylene : paraffin $(1: 1 \mathrm{v} / \mathrm{v}) \quad 20$ minutes

3. Xylene : paraffin $(1: 3 \mathrm{v} / \mathrm{v}) 20$ minutes

4. Paraffin

5. Paraffin

40 minutes

40 minutes

A 10-20 minutes was added for each step to process larvae.

Embedding. This step was carried out using a mold made of thick paper or stainless steel. The mold was filled with liquefied paraffin, and the specimen was placed into it. The specimen was carefully orientated in the mold according to intended plane of section. A cassette has been put on top of the mold and was topped up with more paraffin then let the paraffin to solidify at room temperature or on a cold plate. In case the cassette is not available, it can be replaced by a holder made of wood. The cassettes or the specimen holders were labeled according to the sample's code.

Microscope Slides Coating. This step was conducted to provide a media allowing the tissue in the paraffin ribbon to attach properly onto the microscope slide. Microscope slide coating is crucial to avoid tissue loss during the staining process. $1 \%$ gelatine solution was prepared by sprinkling 10 $\mathrm{g}$ of gelatin powder on the surface of $1 \mathrm{~L}$ of boiling distilled water. Let the gelatin to dissolve by itself since steering the solution will lead to foam or bubble formation result in a bad quality of the coating. The blank new microscope slides were placed onto the slide rack, deep into the gelatine solution for three times, drained on the tissue paper then were put into an oven incubator at $40^{\circ} \mathrm{C}$ overnight. The coated slides were ready to used and can be stored for months in a dry place.

Sectioning and Affixing. The paraffin blocks containing specimen were trim to reduced access of paraffin, the distance between the edge of the tissue and the edge of paraffin was approximately $5 \mathrm{~mm}$. The blocks were then clamped into the microtome for sectioning. The specimens were cut at 4-5 $\mu \mathrm{m}$ thick to provide good histological detail and reduce overlap between cells in a section. The paraffin ribbons were put into $5 \%$ ethanol solution then into lukewarm water (preferably using a water bath) to let the ribbon containing the tissue sections to expand. The ribbons were then scooped onto the coated microscope slides and let them dry at room temperature or in an oven incubator at $37^{\circ} \mathrm{C}$ overnight.

Staining. The sections were deparaffinized by immersing them into xylene for 2 minutes twice, followed by rehydration in a series of decreasing ethanol. After rinsing the slide in distilled water, the sections were dipped into hematoxylin solution for 2 minutes followed by rinsing in running tap water for 2 minutes. The sections were counterstained with eosin for 1 minute followed by rinsing in running tap water then were dehydrated in a series of increasing ethanol, cleared in xylene solution and were mounted with enthelan new. The staining sequence was:
1. Xylene
2. Absolute ethanol
$2 \times 2$ minutes with agitation
3. $90 \%$ ethanol
4. $80 \%$ ethanol
$2 \times 30$ dips
5. $70 \%$ ethanol 30 dips
6. Distilled water 30 dips
7. Mayer Hematoxylin 2 minutes
8. Running tap water 1 minute
9. Scott's water 5-8 second
10. Running tap water 1 minute
11. Eosin 30-60 seconds
12. Running tap water 1 minute
13. Distilled water 30 dips
14. $70 \%$ ethanol 30 dips
15. $80 \%$ ethanol $\quad 30$ dips
16. 90 ethanol $\quad 30$ dips
17. Absolut ethanol $2 \times 30$ dips
18. Xylene $2 \times 30$ dips

The microscope slides were drained then 2-3 drops of Enthelan were placed over the sections. The coverslips were then put slowly on one side of the Enthelan droplet to avoid entrapping air bubbles.

\section{RESULTS AND DISCUSSION}

The protocol described in this paper works well and produces consistent results. Some of the results were presented in Figure 1. Each step in preparing histological section including tissue collection, fixation, dehydration, clearing, infiltration and embedding might contribute to the quality of histological features. 

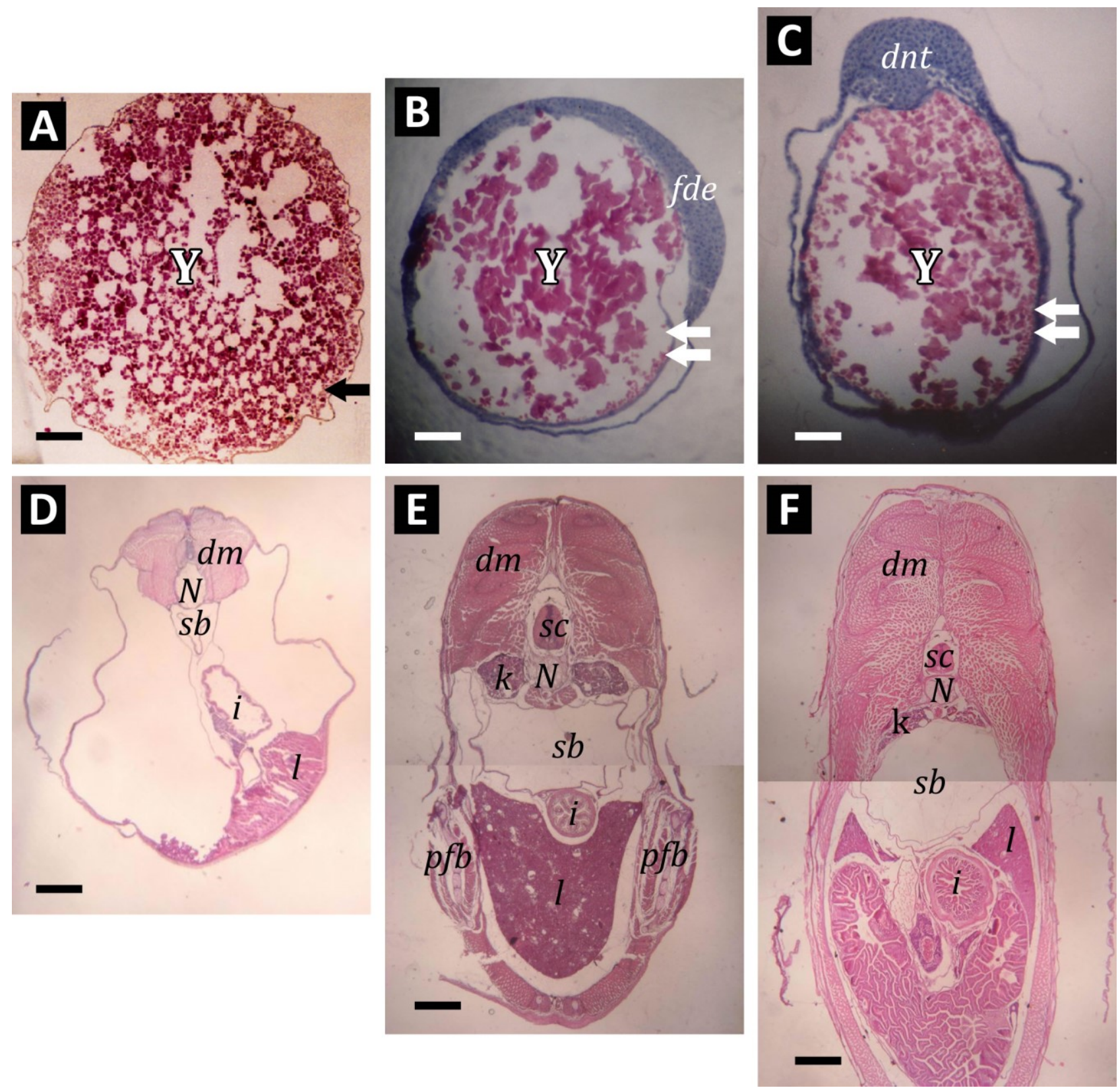

Figure 1. Cross section of giant gourami egg (A), hard-lipped barb embryo at late gastrula (B), and head-tail (C) stages. Giant gourami larvae of $5 \mathrm{dph}$ (D), $20 \mathrm{dph}$ (E) and $60 \mathrm{dph}$ (F). dm: dorsal muscle, dnt: developing neural tube, fde: future dorsal side of the embryo, i: intestine, k: kidney, l: liver, N: notochord, sb: swim bladder, Y: yolk, single black arrow: chorion, double white arrow: yolk sac. Bars represent: $400 \mu \mathrm{m}$ in A, $200 \mu \mathrm{m}$ in B-C, $650 \mu \mathrm{m}$ in D and $2 \mathrm{~mm}$ in E-F

Tissue freshness is very crucial for good histological results; therefore the embryos and larvae were fixed straight away after removal. The maximum delay between sample collection and fixation was varied according to the type of the tissue. Embryonic tissues are more fragile than the more developed tissues; therefore the tissues must be fixed as soon as they were collected (Pinchbeck et al., 2001). Maximum delay between availability of the dead animal and fixation was 15-20 minutes for delicate embryonic tissues (Pinchbeck et al., 2001) and 45-50 minutes for adult tissues (Mayer et al. 2003).

The purpose of fixation was to prevent autolysis and distortion of the tissue structure. Proper fixation is critical to preserving cells and tissue structure as close as possible to their in vivo condition.Fixation results could be influenced by several factors such as sample size, fixative solution, and temperature. Mayer and Hornicle (2010) recommended that the sample size should have maximum area of $5 \times 10 \mathrm{~mm}$ and thickness of $5 \mathrm{~mm}$, to let the fixative medium penetrate rapidly into the tissue and ensure proper fixation quality. A bigger size of tissue can be fixed intact as far as the ratio of tissue or sample to fixative volume is sufficient. The recommended optimum ratio between tissue and fixative volume is $1: 10$ to $1: 20$ (Kang et al., 2003; Knoblaugh et al., 2012). Most laboratories apply a standard ratio of tissue to the fixative volume of 1:10 (Hewitt et al., 2008). A lower volume of fixative can be used as far as frequent 
changes of the fixative are carried out to prevent exhaustion (National Diagnostics 2011). In our study, the ratio of tissue to fixative volume was $1: 20$.

Fish of different developmental stages need different handling. Early embryonic stages, from cleavage to late gastrula, are very susceptible to damage (Wijayanti et al., 2010). Fish larvae, particularly in the stage of yolk absorption and fin formation, are fragile. Therefore they needed a fast penetrating fixative solution to prevent them from damage. The fish larvae fixed in Bouin solution showed better histological features than those fixed in Formaldehyde (data not shown). This feature might be due to the advantage of Bouin. Bouinpenetrate into the tissue more rapidly and evenly. It is also less damaging to the conformation of proteins than formaldehyde alone (James \& Tas, 1984). Thus Bouin maintains fine tissue structure and prevents tissue shrinkage during the fixation step (James \& Tas, 1984). Also, Bouin solution is relatively independent of temperature influence and can be performed at room temperature (Pearse, 1985). The yellow appearance of Bouin is also beneficial for embryo fixation. The size of hard-lipped barb embryos was approximately $1 \mathrm{~mm}$; their size became smaller after clearing step; in such condition, the yellow color of Bouin provide a great help in orienting embryo during embedding step.

Decalcification improved histological features of the hard-lipped Barb and giant gourami larvae. The un-decalcified samples especially around the vertebrae and the base of the fins were easier to get crack than the decalcified one. The type of decalcifying solution and the duration of decalcification are varied. In our study, decalcification of giant gourami fry size of $34.5 \mathrm{~mm}$ using 5\% Trichloroacetic acid for 36 hours was sufficient to produce good quality of the histological feature. Other researcher decalcified the tissue in $10 \%$ sodium-citrate $/ 22.5 \%$ formic-acid $\mathrm{pH}$ 2.5 for 24 hours and 0.5 M EDTA pH 7.8 for 7days (More et al., 2002) or 7\% EDTA, 8-10\% formic acid or 8-10\% formal-nitric acid (Prasad \& Donoghue, 2013).

A thorough dehydration and clearing are critical for paraffin embedding. Incomplete dehydration hinder infiltration since paraffin is not mixed well with water. Poor infiltration resulted in the tissue to crack during sectioning. Empty paraffin ribbon is one of the examples of improper infiltration. The duration of infiltration should also be carefully studied. If the length of infiltration is too short, the paraffin will not properly get into the tissue. On the other hand, if the duration is too long the tissue will become harden and difficult to be cut.

A suitable embedding process will produce good histological feature when a proper staining procedure follows it. Removing paraffin from the tissue is critical before proceeding to the staining step. Un-thorough paraffin removal will prevent the staining solution entering the tissue section lead to a poor staining quality such as weak and spotty staining. Un-thorough paraffin removal will also reduce the clarity and detail of the tissue structure. Several steps including rehydration before staining, dehydration, and clearing after staining, also contribute to the quality of the histological features. Last but not least mounting the tissue sections with a mounting agent has to be conducted properly since too much solvent left on the tissue section stimulate bubble formation. On the other hand, when the tissues were left too dry it will result in black nucleoli appearance.

\section{CONCLUSION AND RECOMMENDATION}

Any step in preparing histological section might contribute to the quality of histological features. A proper knowledge of the tissues beeing processed, fixative solution and the histological techniques is essential to gain good results. Decalcification is necessary to produce useful histological sections on the specimens containing bone.

\section{ACKNOWLEDGEMEN T}

Authors would like to thank Heni Wahyuningsih and Rochyati for their assistance on microtomic work.

\section{REFERENCES}

Balogh E, Sótonyi P. 2003. Histological studies on embryonic development of the rabbit heart. Acta Veterinaria Hungarica 51(1):1-13.

Carmago MMP, Martinez CBR. 2007. Histopathology of Gill, Kidney, and Liver of Neotropical Fish Caged in an Urban Stream. Neotropical Ichthyology 5(3):327-336.

Greaves P. 2007. 2 - Integumentary System. In: Histopathology of Preclinical Toxicity Studies. p. 10-67. [accessed 2017 May]. https://doi.org/10.1016/B978-044452771-4/50003-1

Habashy MM, Sharshar KM, Hassan MMS. 2012. Morphological and histological studies on the embryonic development of the freshwater prawn, Macrobrachium rosenbergii (Crustacea, Decapoda). J. Basic Appl. Zool. 65:157-165. [accessed 2017 May]. https://doi.org/10.1016/j.jobaz.2012.01.002

Hewitt HSM, Lewis FA, Cao Y, Conrad YC, Cronin M, Danenberg KD, Goralski TJ, Langmore JP, Raja RG, Williams PM, Palma JF, Warrington JA. 2008. Tissue Handling and Specimen Preparation in Surgical Pathology: Issues Concerning the Recovery of Nucleic Acids From Formalin-Fixed, ParaffinEmbedded Tissue. Arch Pathol. Lab Med 132:1929-1935

James J, Tas J. 1984. Histochemical Protein Staining Methods (Microscopy Handbooks 04). Oxford, Md: Oxford Univ Press, Royal Microscopy Society

Kang QK, Labreck JC, Gruber HE, An YH. 2003. Histological Techniques for Decalcified Bone and cartilage. In An YH, Martin KL Editors. Handbook of Histology Methods for Bone and Cartilage.Totowa: Humana Press Inc. pp 209-220

Knoblaugh S, Randolph-Habecker J, Rath S. 2012. Necropsy and Histology. In. Treuting PM, Dintzis SM. Editors. Comparative Anatomy and Histology: A Mouse and Human Atlas. New York: Academic Press. pp 15-37

Mathew ES, Appel B. 2016. Oligodendrocyte Differentiation. In Detrich III HW, Westerfield M, Zone LI. Editors. The Zebrafish: Cellular and Developmental Biology, Part B, Developmental Biology $4^{\text {th }}$ Edition, Method in Cell Biology Vol 134. New York: Academic Press. pp 70-88

Matsuda Y, Fujii T, Suzuki T, Yamahatsu K, Kawahara K, Teduka K, Kawamoto Y, Yamamoto T, Ishiwata T, Naito Z. 2011. Comparison of Fixation Methods for Preservation of Morphology, RNAs, and Proteins From Paraffin-Embedded Human Cancer Cell-Implanted Mouse Models. Journal of Histochemistry \& Cytochemistry 59(1):68-75

Mayer W, Zschemuch NH, Godynicki S. 2003. The Porcine ear Skin as a Model System for Human Integument; influence of Storage 
Condition on Basic features of Epidermis Structure and Function - a Histological and Histochemical Study. Pol. J. Vet. Sci. 6:17-28

Mayer W, Hornickel IN. 2010. Tissue fixation - the Most Underestimated Methodological Feature of Immunohistochemistry. Mendez-Vilas A, Diaz J (Eds.) Microscopy: Science Technology, Application, and Education pp 953-959

More JL, Aros M, Steudel KG, Cheng KC. 2002. Fixation and decalcification of Adult Zebrafish for Histological, Immunocytochemical and Genotypic Analysis. Short Technical Report. BioTechniques 32:296-298

National Diagnostic. Histology: Factors Affecting Fixation [internet]. Atlanta, Georgia, USA. [cited 2017 May] available from. https://www.nationaldiagnostics.com/histology/article/factor s-affecting-fixation

Nuckels RJ, Gross JM. 2007. Histological preparation of embryonic and adult zebrafish eyes. CSH Protoc.

Palikova M, Navratil S, Tichy F, Sterba F, Marsalek B, Blaha L. 2004. Histopathology of Carp (Cyprinus carpio L.) Larvae Exposed to Cyanobacteria extract. Acta Vet. BRNO 73:253-257

Pearse AGE. 1985. Histochemistry - Theoretical and Applied. 4th ed. Edinburgh, Md: Churchill Livingston

Pinchbeck JB, James TL, Bagnall KM, Bamforth JS, Milos NC. 2001. Preservation of the morphological and molecular stability of embryonic tissues. Biotech. Histochem. 76:43-52.
Prasad P, Donoghue M. 2013. A Comparative Study of Various Decalcification Techniques. Indian Journal of Dental Research. 24(3):302-308

Sabaliauskas NA, Foutz CA, Mest JR, Budgeon LR, Sidor AT, Gershenson JA, Joshi SB, Cheng KC. 2006. Method 39:246-254

Takashima F, Hibiya T. 1985. An Atlas of Fish Histology Normal and Pathological Features. Kudansha Ltd. Tokyo.

Treuting PM, Dintzis SM, Montline KS. 2012. Introduction. In. Treuting PM, Dintzis SM. Editors. Comparative Anatomy and Histology: A Mouse and Human Atlas. New York: Academic Press. pp 1-5

Wijayanti, GE. 2003. Pre and Postnatal Development of the Germ Cells in a Marsupial, the Tammar Wallaby. Ph.D. Thesis. Melbourne, Australia: The University of Melbourne.

Wijayanti, GE, Soeminto, Simanjuntak SBI. 2009. Profil Hormon Reproduksi dan Gametogenesis Pada Gurami (Osphronemus gouramy Lac) Betina. Jurnal Akuakultur Indonesia 8(1):77-89

Wijayanti GE. Sugiharto, Susatyo P, Nuryanto A, Soeminto. 2010. Perkembangan Embryo dan larva Ikan Nilem yang Diinkubasi Pada Medium Dengan Berbagai Temperatur. Proceeding $7^{\text {th }}$ Basic Sciences National Seminar. 20 Februari 2010. Malang: FMIPA Universitas Brawijaya. 1:1-298 